\title{
History of Pesticide Exposure as a Risk Factor for Spontaneous Abortion in Female Farmers in Bandungan District, Semarang Regency
}

\author{
Siti Qomariyah, Onny Setiani, Suhartono
}

Faculty of Public Health, Diponegoro University - Semarang

Email:qomariyah24@gmail.com

\begin{abstract}
Abortion is the termination of pregnancy before the fetus can live outside the womb, namely the age of fewer than 20 weeks of gestational age with a fetal weight of fewer than 500 grams (The prevalence of spontaneous abortion throughout the world varies, but generally reaches $0.3 \%$. Abortion rates among farmer's exposure to pesticides are as much as $9 \%$. Several studies report that women who have exposure to pesticides or work in the agricultural sector are at risk of spontaneous abortion.

The study uses case-control, involving 42 case group respondents and 42 control group respondents in Bandungan District. The variables studied were a history of pesticide exposure (the degree of pesticide exposure, the practice of pesticide use, the practice of storing pesticides, the type of pesticide) with the incidence of spontaneous abortion. Analysis using the Chi-square test.

The results showed an association between the practice of storing pesticides with spontaneous abortion ( $p$ value $=0.030$, OR $=3.301 C I 95 \%)$, organophosphate pesticide types $(p$ value $=0.038$, OR $=3.210$ CI 95\% $)$, carbamate pesticides ( $p$ value $=0.008$, OR $=0.200$ CI 95\%).

Keywords - spontaneous abortion incidence, history of pesticide exposure, Semarang.
\end{abstract}

\section{INTRODUCTION}

Abortion is the termination of pregnancy before the fetus can live outside the womb, namely the age of fewer than 20 weeks of gestational age with a fetal weight of fewer than 500 grams. ${ }^{(1)}$ The prevalence of spontaneous abortion throughout the world varies but generally reaches $0.3 \%$, while the prevalence of abortion in Iran in 2014 it reached $45.7 \%$ among 2,470 pregnant women. The proportion of spontaneous abortion reaches $74.2 \%$ of all abortion events. The rate of abortion among farmers exposed to pesticides is as much as $9 \% .^{(2)}$ The risk of spontaneous abortion has been studied in manyblood groups of workers using pesticides in various countries, both in America, Europe, and Indonesia.

Some studies report that women who have exposure to pesticides or work in the agricultural sector are at risk of spontaneous abortion. ${ }^{(3)}$ The Food and Agriculture Organization (FAO) said that the latest data on women working in the agricultural sector in developing countries is $43 \%$, including Indonesia. ${ }^{(4)}$ More than 140,000 pesticides used every year in the European Union are only for agriculture. ${ }^{(5)}$ Pesticides are thought to cause harmful short-term health effects and for various chronic effects. Acute health effects include stinging eyes, rash, blisters, blindness, nausea, dizziness, diarrhea, and death. ${ }^{(6)}$ The adverse effects of pesticides are also feared to increase reproductive disorders in humans, from subfertility to abortion and malformation. ${ }^{(7)}$

The risk of spontaneous abortion has been studied in many groups of workers who use pesticides. An increased incidence of visible spontaneous abortion in wives of workers who use pesticides in Italy, India and the United States, green homeworkers in Colombia and Spain, garden workers in Argentina, sugar cane farmers in Ukraine, and women involved in the agricultural sector in the United States and Finland. A study of 209 life partners in Italy, who worked in greenhouse gardens, had an increased risk of spontaneous abortion due to exposure to pesticides with $\mathrm{OR}=11.8 .^{(8)}$

\section{METHOD}

This type of research is analytically using a case-control study, namely research by comparing between case groups and control groups based on their exposure status (retrospective). The design of this study uses the interview survey method with a questionnaire. The study began by identifying subjects who experienced the effects (case group) and looked for subjects who did not experience the effects (control group) of the two groups studied and then compared. 
This research was conducted in Bandungan District, Semarang Regency, the working area of Duren and Jimbaran Health Centers. The population in this study consisted of the population of the case group and the control group. The case population in this study were women who worked as farmers who were pregnant in 2018, residing in Bandungan Subdistrict and had a history of spontaneous abortion, while for the control population was women who worked as farmers who became pregnant in 2018, living in Bandungan District and can give birth to the baby safely.Sampling in this study using total sampling, meaning that the entire number of cases used as research samples. In Bandungan Subdistrict in 2018, there were 42 cases of spontaneous abortion, while for the control group it was taken as many as 42 respondents, so in this study, there were 42 respondents in the control group and 42 respondents in the case group. Data obtained from primary data and secondary data.

\section{RESULT}

1) Characteristics of respondents

Table 1. Characteristics of respondents

\begin{tabular}{lllllll}
\hline \multirow{2}{*}{ No } & Characteristics & \multicolumn{3}{c}{ Case } & \multicolumn{2}{c}{ Control } \\
\cline { 3 - 6 } & $\mathbf{n}(\mathbf{4 2})$ & \% & (42) & $\%$ \\
\hline
\end{tabular}

1. Number of pregnancies (parity)

$\begin{array}{ccccc}\geq 4 & 1 & 1,4 & 1 & 2,4 \\ <4 & 41 & 97,6 & 41 & 97,6\end{array}$

The distance of labor with the next

2. pregnancy

$$
\begin{aligned}
& \geq 2 \text { years } \\
& <2 \text { years } \\
& \text { Education }
\end{aligned}
$$

3.

Not completed in primary school primary school

Junior high school

Senior High School

Involvement of agricultural activities before pregnancy

Yes

No

Helps prepare pesticides

Yes

No

Helps to mix/mix pesticides

Yes

No

Helps spray

Yes

No

Wash your husband/father's clothes while spraying

Yes

No

Throw away grass

Yes

No

Watering the plants 


\begin{tabular}{|c|c|c|c|c|c|}
\hline \multirow{2}{*}{ No } & \multirow[t]{2}{*}{ Characteristics } & \multicolumn{2}{|c|}{ Case } & \multicolumn{2}{|c|}{ Control } \\
\hline & & n (42) & $\%$ & n (42) & $\%$ \\
\hline \multirow{29}{*}{5} & Yes & 41 & 97,6 & 42 & 100 \\
\hline & No & 1 & 2,4 & 0 & 0 \\
\hline & Harvest & & & & \\
\hline & Yes & 39 & 92,9 & 39 & 92,9 \\
\hline & No & 3 & 7,1 & 3 & 7,1 \\
\hline & $\begin{array}{l}\text { Involvement of agricultural } \\
\text { after being declared pre }\end{array}$ & & & & \\
\hline & Yes & 42 & 100 & 42 & 100 \\
\hline & No & 0 & 0 & 0 & 0 \\
\hline & Helps prepare pestici & & & & \\
\hline & Yes & 6 & 14,3 & 5 & 11,9 \\
\hline & No & 36 & 85,7 & 37 & 88,1 \\
\hline & Helps to mix/mix pesti & & & & \\
\hline & Yes & 4 & 9,4 & 4 & 9,4 \\
\hline & No & 38 & 90,5 & 38 & 90,5 \\
\hline & Helps spray & & & & \\
\hline & Yes & 1 & 2,4 & 4 & 9,5 \\
\hline & No & 41 & 97,6 & 38 & 90,5 \\
\hline & $\begin{array}{l}\text { Wash your husband/father } \\
\text { while spraying }\end{array}$ & & & & \\
\hline & Yes & 42 & 100 & 40 & 95,2 \\
\hline & No & 0 & 0 & 2 & 4,8 \\
\hline & Throw away grass & & & & \\
\hline & Yes & 36 & 85,7 & 34 & 81 \\
\hline & No & 6 & 14,3 & 8 & 19 \\
\hline & Watering the plant & & & & \\
\hline & Yes & 14 & 33,3 & 27 & 64,3 \\
\hline & No & 28 & 66,7 & 15 & 35,7 \\
\hline & Harvest & & & & \\
\hline & Yes & 19 & 45,2 & 20 & 47,6 \\
\hline & No & 23 & 54,8 & 21 & 47,7 \\
\hline
\end{tabular}

The table above shows that the case group was 42 respondents. In the case group, cases with a number of pregnancies (parity) $<4$ were 41 people $(97.6 \%)$, had a distance of labor with the next pregnancy $<2$ years 19 respondents $(45.2 \%)$, elementary education as many as 27 respondents $(64,3 \%), 42$ farmers $(100 \%)$ who had prepregnancy farming activities, helped prepare 19 pesticides for respondents (45.2), helped mix / mix pesticides as many as 19 (45.2) respondents, helped spray as much as 5 respondents (11.9), washing husband / father's clothes while spraying as many as 42 respondents (100\%), removing grass as much as 42 respondents (100\%), watering plants as many as 41 respondents (97.6). Whereas for 42 farmers (100\%) who had agricultural activities after pregnancy, helped prepare 6 pesticides for the respondents (14.3\%), assisted in mixing / mixing pesticides by 4 respondents (9.5), helping to spray 1 respondent's land (2.4\%), washing husband / father's clothes while spraying 42 respondents $(100 \%)$, removing grass as much as 36 respondents $(85.7 \%)$, watering plants as many as 14 respondents (33.3\%), harvesting as many as 19 respondents $(45.2 \%)$.

The history of pesticide exposure is seen from four variables, namely the degree of exposure to pesticides (seen from the use of PPE, length of work, a period of work) the practice of pesticide use, the practice of storing pesticides, and the type of pesticide.

2) Relationship of a degree of exposure to the incidence of spontaneous abortion 
Table 2. Relationship of a degree of exposure to the incidence of spontaneous abortion

\begin{tabular}{cccccc}
\hline Degree of & \multicolumn{2}{l}{ Incidence of spontaneous abortion } & & \\
\cline { 2 - 6 } exposure & $\begin{array}{c}\text { Case } \\
(\mathbf{n = 4 2})\end{array}$ & $\begin{array}{c}\text { Control } \\
(\mathbf{n = 4 2})\end{array}$ & $\boldsymbol{P}$ & OR & (CI 95\%) \\
\hline High & $9(21,4 \%)$ & $7(16,7 \%)$ & & \\
Middle & $29(69 \%)$ & $23(54,8 \%)$ & 0,973 & 1,020 & $(0,330-3,154)$ \\
Low & $4(9,5 \%)$ & $12(28,6 \%)$ & & & \\
\hline
\end{tabular}

Based on table 2 The research results showed no meaningful link between the degree of exposure of pesticides with spontaneous abortion incidence ( $\mathrm{p}$ value value 0.973 ). The proportion of high exposure degrees in case groups is $21.4 \%$ higher than that of the $16.7 \%$ control group.

3) Relationship between the practice of pesticide use and the incidence of spontaneous abortion

\begin{tabular}{cccccc}
\multicolumn{5}{c}{ Table 3. Relationship between the practice of pesticide use and the incidence of spontaneous abortion } \\
\hline $\begin{array}{c}\text { The practice } \\
\text { of using } \\
\text { pesticides }\end{array}$ & $\begin{array}{c}\text { Incidence of spontaneous abortion } \\
(\mathbf{n = 4 2})\end{array}$ & $\begin{array}{c}\text { Control } \\
(\mathbf{n = 4 2})\end{array}$ & $\boldsymbol{P}$ & OR & (CI 95\%) \\
\cline { 2 - 6 } Bad & $\begin{array}{c}32 \\
(38,1 \%)\end{array}$ & $23(27,4 \%)$ & & & \\
Good & $\begin{array}{c}10 \\
(11,9 \%)\end{array}$ & $19(22,6 \%)$ & 0,039 & 2,643 & $(0,446-2,788)$ \\
\hline
\end{tabular}

Based on the thick 3 results showed there is a meaningful contact between the practices of pesticide use with spontane ous abortion incidence ( $\mathrm{p}$-value $0.039, \mathrm{OR}=2.643$, CI 95\% 1,038-6,731). Proportion of poor pesticide use practices in case groups of $38.1 \%$ higher than those of the $27.4 \%$ control group.

4) Relationship between the practice of storing pesticides and the incidence of spontaneous abortion

Table 4. Relationship between the practice of storing pesticides and the incidence of spontaneous abortion

\begin{tabular}{cccccc}
\hline The practice of & \multicolumn{3}{c}{ Incidence of spontaneous abortion } & & \\
\cline { 2 - 5 } storing pesticides & $\begin{array}{c}\text { Case } \\
(\mathbf{n = 4 2})\end{array}$ & $\begin{array}{c}\text { Control } \\
(\mathbf{n = 4 2})\end{array}$ & $\boldsymbol{P}$ & OR & (CI 95\%) \\
\hline Inside the house & $24(57,1 \%)$ & $10(23,8 \%)$ \\
Outside the house & $18(42,9 \%)$ & $32(76,2 \%)$ & 0,004 & 4,267 & $(1,672-10,888)$ \\
\hline
\end{tabular}

Based on table 4 The research results showed a meaningful link between the pesticide storage practice with spontaneous abortion ( $\mathrm{p}$ value value $0.004, \mathrm{OR}=4.267, \mathrm{CI} 95 \%=1,672-10,888$ ). Proportion of pesticide storage practices in the home in case groups of $57.1 \%$ higher than the $23.8 \%$ control group.

5) Relationship to the type of pesticide with the incidence of spontaneous abortion

Table 5. Relationship to the type of pesticide with the incidence of spontaneous abortion

\begin{tabular}{|c|c|c|c|c|c|c|}
\hline \multirow{2}{*}{$\begin{array}{l}\text { Types of } \\
\text { pesticides }\end{array}$} & & \multicolumn{5}{|c|}{ Incidence of spontaneous abortion } \\
\hline & & $\begin{array}{c}\text { Case } \\
(n=42)\end{array}$ & $\begin{array}{l}\text { Control } \\
(n=42)\end{array}$ & $\boldsymbol{P}$ & $\mathbf{O R}$ & (CI 95\%) \\
\hline \multirow{4}{*}{ Organophosphate } & Yes & 39 & 35 & \multirow{4}{*}{0,313} & \multirow{4}{*}{2,600} & \multirow{4}{*}{$(0,624-10,837)$} \\
\hline & & $(46,4 \%)$ & $(41,7 \%)$ & & & \\
\hline & No & 3 & 7 & & & \\
\hline & & $(3,6 \%)$ & $(8,3 \%)$ & & & \\
\hline \multirow{4}{*}{ Carbamate } & Yes & 31 & 40 & \multirow{4}{*}{0,002} & \multirow{4}{*}{0,183} & \multirow{4}{*}{$(0,064-0,527)$} \\
\hline & & $(36,9 \%)$ & $(47,6 \%)$ & & & \\
\hline & No & 11 & 2 & & & \\
\hline & & $(13,1 \%)$ & $(2,4 \%)$ & & & \\
\hline
\end{tabular}




\begin{tabular}{ccccccc}
\hline \multirow{3}{*}{ Pyrethroids } & Yes & $\begin{array}{c}14 \\
\end{array}$ & $\begin{array}{c}10 \\
(33,3 \%)\end{array}$ & 0,186 & 1,800 & $(0,751-4,315)$ \\
\cline { 2 - 5 } & No & $28,8 \%)$ & & & \\
& & $(66,7 \%)$ & $(76,2 \%)$ & & & \\
\hline
\end{tabular}

\section{Organophosphate}

Based on table 5 pesticide use type organophosphate research results shows no significant link between the use of organophosphate type of pesticide with spontaneous abortion incidence of $\mathrm{P}$ value 0.313 . The proportion that uses the type of organophosphate pesticides in the case group is $46.4 \%$ greater than the control group $41.7 \%$.

\section{Carbamate}

Based on the results shows there is a significant relationship between the use of the type of carbamat pesticides with spontaneous abortion ( $p$ value of 0.007 , $\mathrm{OR}=0.141$, CI 95\% =0,029-0,683). The proportion of the karbamic pesticide type in the case group is $36.9 \%$ smaller than that of the $47.6 \%$ control group.

\section{Pyrethroids}

Table 6. Historical variable candidates for pesticide exposure are more dominant in the incidence of spontaneous abortion

\begin{tabular}{ccccc}
\hline No & Risk factor & $P$ & OR & $(95 \%)$ CI \\
\hline 1. & Pesticide Use practices & 0,039 & 2,643 & $(1,038-6,731)$ \\
2. & Pesticide Storage Practice & 0,004 & 4,267 & $(1,672-10,888)$ \\
3. & Types of carbamate pesticides & 0,007 & 0,141 & $(0,029-0,683)$ \\
4. & Types of Pyrethroids pesticides & 0,186 & 1,800 & $(0,751-4,315)$ \\
\hline
\end{tabular}

The following are the results of logistic regression analysis which are obtained as more dominant risk factors for spontaneou s abortion:

\begin{tabular}{cccccc}
\multicolumn{6}{c}{ Table 7. history of pesticide exposure is more dominant in the incidence of spontaneous } \\
\hline No & Risk Factor & $P$ & $\operatorname{Exp}(\mathrm{B})$ & $(95 \%) \mathrm{CI}$ & $\mathrm{B}$ \\
\hline 1. & $\begin{array}{c}\text { Pesticide Storage } \\
\text { Practice }\end{array}$ & 0,002 & 4,747 & $(1,736-12,976)$ & 1,557 \\
& $\begin{array}{c}\text { Types of carbamate } \\
\text { pesticides } \\
\text { Constant }\end{array}$ & 0,014 & 0,126 & $(0,024-0,662)$ & $-2,075$ \\
& $\quad$ & & & -880 \\
\hline
\end{tabular}

Based on a table of 7 multivariate analysis results with a logistic regression analysis shows that of the three variables of the most dominant pesticide exposure history against the spontaneous aborts that are the pesticide storage practices with the value of $\mathrm{p}$ value $=0.003(\mathrm{OR}=$ 4.606 CI $95 \%$ 1,667-12,726), the type of pesticide class with the value of $\mathrm{p}$ value $=0.017(\mathrm{OR}=0.131 \mathrm{CI} 95 \%=$ 0,062-0,710).

Based on the outcome of these women farmers who keep pesticides poorly have a risk of spontaneous abortion incidence 4 times compared with women farmers who
Based on the results of the study showed no significant link between the use of the type of pyrethroids pesticide types with spontaneous abortion incidence of $\mathrm{P}$ value 0.469 . The proportion of the pyrethroids pesticide type in the case group is $33.3 \%$ smaller than that of the $23.8 \%$ control group.

The next analysis uses multivariate analysis, which is to find out more dominant risk factors for the incidence of spontaneous abortion. The variables to be analyzed are variables that have a value of $p$-value $<0.25$, these variables include the following:

6) Historical variable candidates for pesticide exposure are more dominant in the incidence of spontaneous abortion 
The results of the statistical analysis in the study stated that several risk factors showed a relationship between the incidence of spontaneous abortion, (p-value <0.05), among others: storage of pesticides, use of types of pesticides, organophosphate and carbamate.

The risk of spontaneous abortion has been studied in several groups of workers who use pesticides. An increased incidence of visible spontaneous abortion in wives of workers who use pesticides in Italy, India and the United States, green homeworkers in Colombia and Spain, garden workers in Argentina, sugar cane farmers in Ukraine, and women involved in the agricultural sector in the United States and Finland. A study of 209 life partners in Italy, who worked in greenhouse gardens, had an increased risk of spontaneous abortion due to exposure to pesticides with an OR value of 11.8. ${ }^{\left({ }^{8}\right)}$

The variable degree of exposure in this study was determined based on the length of work, work period and use of personal protective equipment. The results showed that in general the level of exposure in respondents tended to be moderate (case group 29 respondents, control group 23 respondents), because it was seen from work period, respondents who had moderate degrees of exposure had work periods of less than 15 years, and for length of work, respondents not working in the field more than 8 hours / day, while for the use of PPE (personal protective equipment) respondents always use personal protective equipment at least three personal protective equipment.

Working period is the length of time since the respondent is active as a farmer until the time the research is conducted in units of years. A person's working period is one of the factors that influence the degree of cholinesterase in the respondent's blood, where the longer the period of work, the lower the level of cholinesterase in the blood of the respondent so the risk of pesticide poisoning. ${ }^{(9)}$

The duration of exposure to pesticides occurs both outdoor which includes exposure to spraying, exposure to agricultural areas, and the location of houses adjacent to agricultural land, and in-door exposure to pesticides includes exposure to pesticides due to storage of pesticides in the home including: in the kitchen, dining room, bedroom, bathroom.

Results showed that there is a relationship between pesticide use practices with spontaneous abortion with the value of $\mathrm{p}$ value $0.039 \mathrm{OR}=2.634 \mathrm{CI} 95 \% 1,038$ 6,73.This is because there are some farmers who are blending pesticides close to the water source, a selfprotection tool that is used only gloves. In the guidance Manual of the use of pesticides by the Ministry of Agriculture mentioned that masks and gloves must be used because when mixing, pesticides can enter through respiratory and skin.

The results showed that a poor farmer's behavior in storing pesticides such as being stored in the house, close to the kitchen and bathroom, were not placed in a special room with ventilation, were not given the danger of having spontaneous abortion 4, 3 times compared to female farmers who have good and right behavior in how to store pesticides at home. This is in line with the research conducted by Fifti Istikhlaili (2009) which states that there is a relationship between the storage of pesticides and the incidence of spontaneous abortion with OR 8.5.

Storage of pesticides is one of the factors that need to be considered in the use of pesticides. Pesticides enter the body through various methods, including by penetrating the skin pores by $90 \%$ and through inhalation, digestion or the other by $10 \%$. Therefore, the best ways to prevent poisoning are to avoid direct contact and protect body parts from exposure to pesticides stored in the house. Pesticides should be stored in a special place and safe for anyone, especially children. Places to store pesticides must be locked and not easily accessible to children or even pets. Pesticides must be stored in the original container, if replaced the container must be labeled (name) large and clear in the container and warning signs of danger (for example: CAUTION TO POISON) For storage pesticide warehouse must be well ventilated, if necessary equipped with a fan to remove air ( exhaust fan). And provided clean water, detergent soap, and sand or sawdust to clean or absorb pesticides if one is spilled and there are empty containers to store used pesticide containers before being destroyed. ${ }^{(10)}$

The results showed that there was a relationship between the use of carbamate pesticides and the incidence of spontaneous abortion with a p-value $=0.007(<0.05)$. The OR value of 0.183 indicates that the use of carbamate pesticides is a protection factor.This is in line with the research of Nasrudin (2001) showing the number of types of pesticides used at the same time to cause a synergistic effect will have a risk 3 times (OR 2,972; 95\% CI 1,0473,512 ) greater for the occurrence of poisoning when compared with 1 type of pesticide which is used because of the toxicity and the dose of the pesticide will be stronger so that it gives greater side effects.

Carbamate pesticides are nerve pois ons that have a way of inhibiting cholinesterase. After entering the body, carbamate pesticides will bind the acetylcholinesterase enzyme (AChe) so that AChe becomes inactive and acetylcholine accumulates. Acetylcholine binds to muscarinic and nicotinic receptors in the central and 
peripheral nervous system. This condition causes symptoms of poisoning that affect the whole body and have a wide impact. ${ }^{(11)}$

One of the effects that are of concern at this time is hypothyroidism which is common in farmers who are exposed to pesticides continuously. Hypothyroidism is a condition in which the thyroid gland fails to produce adequate thyroxine (T4) and triiodothyronine (T3) hormones to meet the body's needs. ${ }^{(12)}$ This is caused by the effects of organophosphate and carbamate pesticides which can interfere with endocrine disrupting compounds (EDC) and thyroid function (thyroid disrupting chemicals / TDC). This disorder causes several negative effects including nerve function disorders, fertility, reproductive outcomes, and child development after birth. ${ }^{(13,14)}$

\section{CONCLUSION}

From the analysis of the history of exposure of pesticides to the incidence of abortion, found several variables that have relationships, among other things a variable use practices of pesticides with spontaneous abortion events with values $(\mathrm{P}=0.039$ and $\mathrm{OR}=2.643)$, storage practices Pesticides related to the incidence of spontaneous abortion with values $(\mathrm{P}=0.004$ and $\mathrm{OR}=4.267)$, there is a correlation between the use of carbamat pesticides and spontaneous abortion events $(\mathrm{P}=0.007$ and $\mathrm{OR}=0.186)$. Then a multivariate analysis was conducted to determine the more dominant risk factors for spontaneous abortion by using a logistic regression test by looking at the variable with the $\mathrm{P}-<0.25$ value, from the analysis, to find two exposure history Predominant variables for spontaneous abortion, pesticide storage practice $(\mathrm{P}=$ 0.002 , or $=4,747)$, type of carbamat pesticide $(\mathrm{P}=0.014$, or $=0.126)$.

\section{ACKNOWLEDGMENTS}

The author would like to thank the Semarang District Health Officer, the Head of Jimbaran and Duren Puskesmas for giving the author permission to research Bandungan District. The author also thanked the Village Midwives in Bandungan Subdistrict for providing data for the author's research needs.

\section{REFERENCES}

[1] Winkjosastro H. Ilmu Kebidanan. Jakarta: Yayasan Bina Pustaka Sarwono Prawirohardjo; 2002.

[2] Neghab M, Fard MM, Naziaghdam R, Salahshour N, Kazemi M, Alipour $\mathrm{H}$. The effect of exposure to pesticide on the fecundityof farm workers resident in a rural a region of fars province, southern Iran. Pacific J Trop Biomed. 2014;4(4):324-8.
[3] Arbuckle TE, Lin Z, Mery and LS. An exploratory analysis of the effect of pesticide exposure on the risk of spontaneous abortion in an Ontario farm population. Child Heal [Internet]. 2001;109(8):851-7. Available from: http://ovidsp.ovid.com/ovidweb.cgi?T=JS\&PAGE=referen ce\&D=emed5\&NEWS=N\&AN=2001343348.

[4] FAO. Women in agriculture: Closing the gender gap for development. 2011;3-22.

[5] Ramazzini C. Statement on the control of pesticides in the European Union: A call for action to protecthuman health. Am J Ind Med. 2009;52(2):176-7.

[6] Jeyaratnam J. Acute pesticides poisoning: a major global health problem. World Helath Stat Q. 1990;43(3):139-44.

[7] Gracia A. Pesticide exposure and women's health. Am J Ind Med. 2003;44(6):589-94.

[8] Petrelli G, Figa-talamanca I, Lauria L, Mantovani A. Spontaneous abortion in spouses of greenhouse workers exposed to pesticides. Environ Health Prev Med. 2003;8:77-81.

[9] Sastrawijaya AT. Pencemaran Lingkungan. Jakarta: Rineka Cipta; 2002.

[10] Djojosumarto P. Teknik aplikasi pestisida pertanian. Yogy akarta: Kanisius; 2008.)

[11] Gossel T.A, Bricker JD. Principle of Clinical Toxicology. Toxy cology. 1990; 11(1):77.

[12] Price SA, Wilson LM, editor. Patofisiologi konsep klinis proses-proses penyakit. Edisi ke-6. Jakarta: EGC; 2005.

[13] Campos E, Freire C. Exposure to non-persistent pesticides and thyroid function: a systematic review of epidemiological evidence. Int $\mathrm{J}$ Hyg Environ Health. 2016;219(6):481-97.

[14] Boas M, Feldt-Rasmussen U, Skakkebaek NE, Main KM,. Environmental chemicals and thyroid function: an update. Curr Opin Endocrinol Diabetes Obes. 2009;16(5):385-91. 